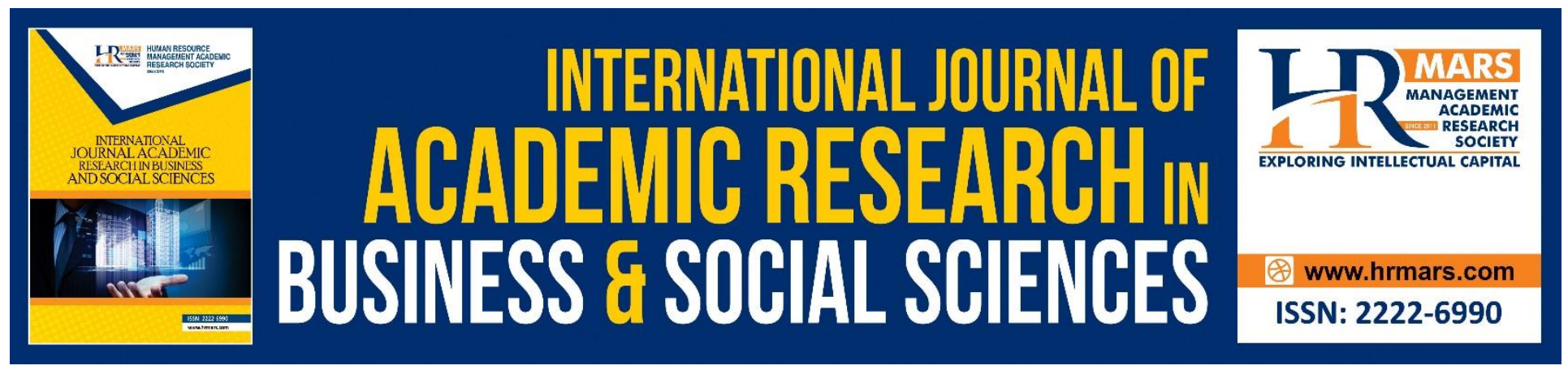

\title{
The Use of 'Teacher in Role' to Facilitate Teaching and Learning of History: Lessons in a Primary School
}

\author{
Sumathi Maniam, Mohd Kipli Abdul Rahman, Junita Batubara
}

To Link this Article: http://dx.doi.org/10.6007/IJARBSS/v9-i5/5858

DOI: $10.6007 /$ IJARBSS/v9-i5/5858

Received: 19 March 2019, Revised: 09 April 2019, Accepted: 24 April 2019

Published Online: 27 May 2019

In-Text Citation: (Maniam, Rahman, \& Batubara, 2019)

To Cite this Article: Maniam, S., Rahman, M. K. A., \& Batubara, J. (2019). The Use of 'Teacher in Role' to Facilitate Teaching and Learning of History Lessons in a Primary School. International Journal Academic Research Business and Social Sciences, 9(5), 287-293.

Copyright: (C) 2019 The Author(s)

Published by Human Resource Management Academic Research Society (www.hrmars.com)

This article is published under the Creative Commons Attribution (CC BY 4.0) license. Anyone may reproduce, distribute, translate and create derivative works of this article (for both commercial and non-commercial purposes), subject to full attribution to the original publication and authors. The full terms of this license may be seen

at: http://creativecommons.org/licences/by/4.0/legalcode

Vol. 9, No. 5, 2019, Pg. 287 - 293

http://hrmars.com/index.php/pages/detail/IJARBSS

JOURNAL HOMEPAGE

Full Terms \& Conditions of access and use can be found at

http://hrmars.com/index.php/pages/detail/publication-ethics 


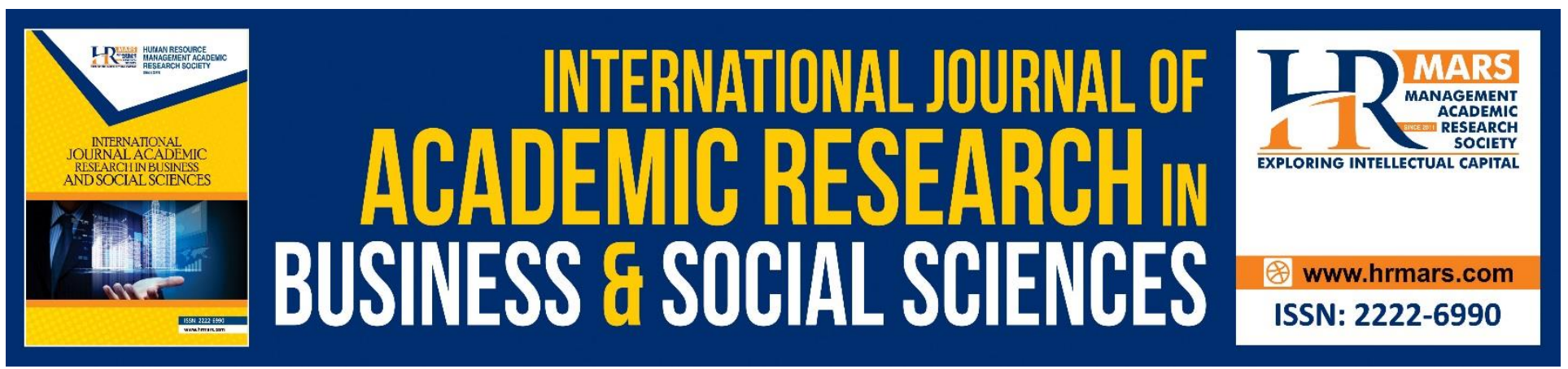

\title{
The Use of 'Teacher in Role' to Facilitate Teaching and Learning of History: Lessons in a Primary School
}

\author{
Sumathi Maniam, Mohd Kipli Abdul Rahman \\ Universiti Pendidikan Sultan Idris, Malaysia \\ Junita Batubara \\ University of HKBP Nommensen, Indonesia
}

\begin{abstract}
Teachers in schools in Malaysia excessively use 'role play' to facilitate their teaching and learning. A form of theatre game known as 'teacher in role' is hardly used by Malaysian teachers although it is an instrumental technique for developing students' learning ability. A research was conducted in a primary school to introduce the method of 'teacher in role'. The teacher or facilitator takes on a role in the drama and plays along with the pupils. The teacher has to choose a piece of costume or a prop to signify that they are in the role. As soon as the teacher puts on the costume or picks up the prop, he/she becomes the chosen character and manages the learning opportunities from within the drama. Education 4.0, emphasizes on a holistic teaching method designed to assimilate critical thinking, scrutiny of emotion and moral values and to expand the learning experience and make it more relevant to everyday life situations and the 'teacher in role' method echos this principal. This research aims to put in practice the 'teacher in role' method in selected classrooms (History) as it can easily be used right across the curriculum to analyses its effectiveness in facilitating teaching and learning. The research will be conducted using the qualitative method in analyzing the effects of the History lessons via 'teacher in role'. The outcome of the research is to re-instate the importance and to introduce history in a more relaxed and fun manner. This research is significant in helping students to liven their imaginary but at the same time to have the liberty to question, challenge and process their thoughts.
\end{abstract}

\section{Introduction}

The researchers would like to first thank Sultan Idris Education University, Tanjong Malim, Perak, Malaysia for granting the Geran Galakan Penyelidikan Universiti (The University Encouragement Research Grant) under the research code 201-0090-107-01 with a sum of RM 5000, which enabled the researchers to conduct the research successfully. In schools, 'role play' is exceptionally used by teachers to expedite teaching and learning. Distinctly, 'teacher in role', a form of theatre game is 
scarcely used by teachers although it is an invaluable technique for shaping the dramatic process and developing students' learning. Upon investigation, the researchers deduced that there is evidently very little research is done on 'teacher in role' and as such, it was distinctively difficulty to source out literary resources on this subject matter. This could be due to the fact that 'teacher in role' is relatively new and not much research has been conducted, and as such, a research based on prospect of 'teacher in role' being a 'teaching tool' was conducted in a primary school in Kuala Lumpur. There are 3 history teachers in the school of which two are female and the other, male. Two of the teachers are experienced in teaching the history subject for less than a year while the other has been teaching this subject for the last five years. The researcher conducted interviews with the teachers to determine their understanding of $21^{\text {st }}$ century teaching and learning and on the 'teacher in role' method. Overall, the teachers do try to incorporate different learning styles based on the $21^{\text {st }}$ century teaching methods and the teachers coherently agree that pupils face difficulties in concentrating, as history lessons require memorization of facts and dates. The teachers have never been exposed to the 'teacher in role' method and had it confused with 'role play'. Explanation was provided as to how 'teacher in role' should be carried out. The researcher then conducted a series of meetings with the teacher concerned (chosen to conduct the teacher in role method based on her experience) and discussion on lesson planning was carried out.

\section{Objectives}

To identify auditory and kinesthetic learning styles through the Teacher in Role method.

\section{Methodology}

The research was based on a qualitative method whereby the sampling included teachers, 22 pupils and school administrators in which data was analyzed. Through this method, the researcher had direct contact with the stakeholders, situation, and phenomenon under investigation; the researchers 'personal experiences and insights were an important part of the inquiry and critical to understanding the phenomenon. As such, this method focuses on data that was obtained based on focus group discussions (FGD) conducted with selected teachers to determine the number of pupils and teachers involved. The stakeholders were selected because they are "information rich" and illuminative. In - depth interviews with stakeholders such as teachers, pupils and administrators was conducted whereby questionnaires were provided before and after the teaching sessions. Pupils, teachers and the administrators were interviewed to gauge their understanding of the Teacher in Role method of teaching and learning. Data was collected through observations of the teaching and learning through the 'teacher in role' method.

\section{Findings}

The researcher chose 22 pupils to participate in this research. A series of Teaching and Learning was conducted to familiarize the pupils with the theatre game, 'Teacher in Role'. A series of questionnaires were given to the students to gauge their understanding before and after the theatre games. Overall, an analysis of the data is as follows: 
INTERNATIONAL JOURNAL OF ACADEMIC RESEARCH IN BUSINESS AND SOCIAL SCIENCES Vol. 9, No. 5, May, 2019, E-ISSN: 2222-6990 @ 2019 HRMARS

\section{Questionnaires Pre - Teacher in Role}

\begin{tabular}{|l|l|l|}
\hline $\begin{array}{l}\text { Question } \\
\text { Number }\end{array}$ & $\begin{array}{l}\text { Number of pupils \& } \\
\text { Percentage (Yes) }\end{array}$ & $\begin{array}{l}\text { Number of pupils \& } \\
\text { Percentage (No) }\end{array}$ \\
\hline 1 & $22(100 \%)$ & 0 \\
\hline 2 & $20(90.91 \%)$ & $2(9.09 \%)$ \\
\hline 3 & $2(9.09 \%)$ & $20(90.91 \%)$ \\
\hline 4 & $4(18.19 \%)$ & $18(81.81 \%)$ \\
\hline 5 & $14(63.64 \%)$ & $8(36.36 \%)$ \\
\hline 6 & $17(77.27 \%)$ & $5(22.73 \%)$ \\
\hline 7 & $19(86.36 \%)$ & $3(13.64 \%)$ \\
\hline 8 & $5(22.73 \%)$ & $17(77.27 \%)$ \\
\hline 9 & $18(81.81 \%)$ & $4(18.19 \%)$ \\
\hline
\end{tabular}

On the whole, based on the data collated, it can be deduced that the pupils agree that that teachers use learning aids during the teaching of History and that they are able to follow the lesson conducted but when it comes to doing revisions, $90.91 \%$ of the pupils do not place importance on revising the history lessons. This can be attributed to the lack of guidance on the subject of history. $81.81 \%$ of pupils also state that they do not favor memorizing historical facts, as it is tedious and time consuming. Interestingly, $36.36 \%$ of pupils admit that they are unable to follow the teacher's teachings in class due to lack of concentration and conventional methods of teachings. $77.27 \%$ agree that essay questions are always a challenge and $81.81 \%$ of pupils state that they are inhibited during exams. As such, the researchers are able to conclude that history lessons taught in the school do not initiate interest amongst the pupils.

The pupils were then presented with the 'teacher in role' method whereby the teacher played a part along with the pupils. The outcome of the lesson is as follows. 
INTERNATIONAL JOURNAL OF ACADEMIC RESEARCH IN BUSINESS AND SOCIAL SCIENCES Vol. 9, No. 5, May, 2019, E-ISSN: 2222-6990 @ 2019 HRMARS

Questionnaires after Teacher in Role was conducted
\begin{tabular}{|l|l|l|l|l|}
\hline Question & $\begin{array}{l}\text { STRONGLY } \\
\text { AGREE }\end{array}$ & AGREE & DISAGREE & $\begin{array}{l}\text { STRONGLY } \\
\text { DISAGREE }\end{array}$ \\
\hline 1 & 5 & 10 & 5 & 2 \\
\hline 2 & 8 & 9 & 3 & 2 \\
\hline 3 & 13 & 6 & 1 & 2 \\
\hline 4 & 6 & 5 & 7 & 7 \\
\hline 5 & 18 & 4 & 0 & 0 \\
\hline 6 & 19 & 2 & 0 & 0 \\
\hline 7 & 16 & 4 & 1 & 1 \\
\hline 8 & 16 & 5 & 1 & 0 \\
\hline 9 & 17 & 3 & 2 & 0 \\
\hline 10 & 16 & 4 & 2 & 0 \\
\hline 11 & 17 & 3 & 2 & 0 \\
\hline 12 & 19 & 3 & 0 & 0 \\
\hline
\end{tabular}

Based on the question I'm not happy when called to answer the question, the answers from the options of strongly agree, disagree and strongly disagree with the same percentage of $23 \%$. $45 \%$ or 10 respondents are not happy to be called upon to answer questions because for them learning the subject of History is difficult. The second question examines if the respondents are comfortable to present their work in front of the class. There are 8 respondents with a 36\% proportion of who strongly agree and $41 \%$ or 9 of the respondents who agree. 6 respondents with a percentage of $27 \%$ disagree and only 2 respondents with $9 \%$ who strongly disagree to present their work in front of the class. As such, the learning of History needs to be further expanded through theatre game techniques.Based on the responses, 13 respondents with a 59\% strongly agree to play roles to further understand the facts of History. Indirectly, respondents can add their own knowledge related to the History lesson being taught. 6 respondents with a percentage of $27 \%$ agree with this statement while respondents with a $18 \%$ percentage disagree and 2 respondents with a percentage of $9 \%$ strongly disagree which shows that students are interested in lessons that inculcates acting.

Through this fourth statement, researcher was comfortable acting without help as many as 6 respondents strongly agree and show a percentage of $27 \%$. In addition, the information also shows 5 respondents with $22 \%$ who agree. However, there is evidence of disagreement and strongly disagree with the same percentage of $31 \%$ which adds up to 7 respondents each. Therefore, the researcher can deduce that respondents are more disagreeable compared to strongly disagree with the process of acting without help. Based on the responses of 18 respondents or $81 \%$ strongly agree with researcher more confident to act when the teacher also acts together while 4 respondents with a percentage of $18 \%$ agree. The data shows that the respondents are more confident to act when the teacher acts together with them. As such, the use of 'teacher in role' in the classroom has positive effects. 19 respondents with a percentage of $86 \%$ strongly agree while 2 respondents or $9 \%$ agree that they enjoy acting in class with the teacher, which adds value to 'teacher in role' on the learning 
of History lessons. The influence of 'teacher on role' on the learning of History can be seen through the evidence "I understand historical facts through acting process" whereby as many as 16 respondents with a percentage of $72 \%$ strongly agree and $18 \%$ or 4 respondents agree and are able to grasp historical facts.

A total of 16 respondents with a percentage of $72 \%$ strongly agree while 4 respondents or $18 \%$ agree with engaging in learning where the teacher plays a role. Only one respondent disagrees with a percentage of $4.5 \%$. This is due to the fact that when the teacher also plays a role (the character) it is easier for the students to understand what is learned in the History lesson. The 'teacher in role' technique can improve one's auditory skills. This statement is strongly supported by 16 respondents or $72 \%$ and 5 respondents or $23 \%$ who agree. As such, the researcher can assert that the objective has been achieved whereby the "teacher in role" technique does indeed enhance the auditory skills and engage students in the learning process. Based on the technique of 'teacher in role', one can improve the mobility (psychomotor) of a person as they are involved in the learning to which 16 respondents or $72 \%$ strongly agree and 4 respondents or $18 \%$ are agreeable. This data proves that kinesthetis skills are incorporated in the 'teacher in role' technique as it involves the movement of students as opposed to them being just immobile during the history lesson. Based on the answers of 17 respondents (77\%), who strongly agree that they are more interested in the History subject if the 'teacher in role' technique is applied in the classroom while 3 respondents agree with a percentage of $13 \%$. As such, this technique is proven to heighten students' interest to the history lesson and provide a platform for them to teach a subject that is labelled as 'factual and boring' to that which induces fun. Based on the answers by 19 respondents who strongly agree with a percentage of $86 \%$ that they do not feel bored in the classroom when learning is done using the technique of Teacher In Role and 2 respondents with a percentage of $9 \%$, demonstrate that the technique of 'teacher in role' has been successfully applied in History subjects by proving that respondents do not feel bored in the classroom.

\section{Conclusion}

As a conclusion, the researcher deduces that auditory and kinesthetic learning styles were incorporated through 'teacher in role' teaching method. This can be observed through the before and after teaching sessions. Pupils were mostly sitting and not paying much attention when conventional teaching methods were used. During the teacher in role method, pupils were at ease to move about and were excited to see their teacher playing a 'role'. Pupils were also keen to listen to the opinions of their teacher and peers 'in character'. Pupils were able to focus and participate in the lesson by producing mind maps based on the 'teacher in role' method. An interview conducted with the teacher concerned also indicated that the 'teacher in role' method was effective in delivering Historical facts. Overall, the 'teacher in role' method was successful in facilitating teaching and learning of history lessons. 
INTERNATIONAL JOURNAL OF ACADEMIC RESEARCH IN BUSINESS AND SOCIAL SCIENCES

Vol. 9, No. 5, May, 2019, E-ISSN: 2222-6990 @ 2019 HRMARS

\section{References}

Bowell, P., Heap, S. B. (2013). Planning Process Drama: Enriching Teaching and Learning. Routledge. Gardner, H. (2011). Frames of mind: The theory of multiple intelligences. New York: Basic Books.

Greene, J. C., Caracelli, V. J., \& Graham, W. F. (1989). Toward a conceptual framework for mixedmethod evaluation designs. Educational Evaluation and Policy Analysis, 11 (3), 255-274.

Farmer, D. (2011). Learning Through Drama in the Primary Years. London: Drama Resources

Farmer, D. (2014). Teacher in Role. Retrieved 13-02-18, from https://dramaresource.com/teacher-inrole/.

Flynn, M. R. (2012). The Teacher in Role Drama Strategy: Start with Character Interviews. Retrieved 13-02-18, from http://dramaticapproachestoteaching.com/post/37087617438/the-teacherin-role-drama-strategy-start-with.

Jacobs, M. M. (2005). Thesis: Drama discovery. Pittsburgh: Duquesne University.

Moore, M. M. (2004). Using drama as an effective method to teach elementary students. Michigan: Eastern Michigan University.

Garba, S. A., Byabazaire, Y., Bustham, A. H. (2015). Toward the Use of 21st Century, Teaching-Learning Approaches: The Trend of Development in Malaysian Schools within the Context of Asia Pacific. Kedah: UUM

Sprenger, M. (2003). Differentiation through Learning Styles and Memory. SAGE Publications

Ministry of Education (2012). Malaysia Education Blue Print 2013-2025-Executive Summary

Dasar Pendidikan Kebangsaan. (2012). Retrieved 2018, from http://www.moe.gov.my/my/dasarpendidikan-kebangsaan. 